\title{
The water vapour distribution in the Arctic lowermost stratosphere during the LAUTLOS campaign and related transport processes including stratosphere-troposphere exchange
}

\author{
A. Karpechko ${ }^{1}$, A. Lukyanov $^{2}$, E. Kyrö ${ }^{1}$, S. Khaikin ${ }^{2}$, L. Korshunov ${ }^{2}$, R. Kivi ${ }^{1}$, and H. Vömel ${ }^{3}$ \\ ${ }^{1}$ Finnish Meteorological Institute, ARC, Sodankylä, Finland \\ ${ }^{2}$ Central Aerological Observatory, Moscow, Russia \\ ${ }^{3}$ Cooperative Institute for Environmental Sciences, University of Colorado, Boulder, USA
}

Received: 6 March 2006 - Published in Atmos. Chem. Phys. Discuss.: 13 June 2006

Revised: 14 September 2006 - Accepted: 11 December 2006 - Published: 10 January 2007

\begin{abstract}
Balloon-borne water vapour measurements during January and February 2004, which were obtained as part of the LAUTLOS campaign at Sodankylä, Finland, $67^{\circ} \mathrm{N}$, were used to analyse the water vapour distribution in the wintertime Arctic lowermost stratosphere. A $2.5 \mathrm{~km}$ thick layer (or $30 \mathrm{~K}$ in the potential temperature scale) above the tropopause is characterized by a significant water vapour variability on a synoptic timescale with values between stratospheric and tropospheric, which is in good agreement with previously reported measurements. A cross-correlation analysis of ozone and water vapour confirms that this layer contains a mixture of stratospheric and tropospheric air masses. Some of the flights sampled laminae of enhanced water vapour above the tropopause. Meteorological analyses and backward trajectory calculations show that these features were related to filaments that had developed along the flanks of cut-off anticyclones, which had been active at this time over the Northern Atlantic. The role of the filaments was however not to transport water vapour from the troposphere to the stratosphere but rather to transport it within the stratosphere away from regions where intensive two-way stratospheretroposphere exchange (STE) was identified. Intensive STE occurred around cut-off anticyclones in regions of strong winds, where calculations suggest the presence of clear-air turbulence (CAT). Evidences that CAT contributes to the troposphere-to-stratosphere transport (TST) are presented. However, statistically, relation between TST and CAT during the studied period is weak.
\end{abstract}

Correspondence to: A. Karpechko

(alex.karpetchko@fmi.fi)

\section{Introduction}

Water vapour is a very important gas for the radiative state of the upper troposphere-lower stratosphere (UTLS) region. Calculations by Forster and Shine (2002) indicate that water vapour trends reported by Oltmans et al. (2000) may have resulted in a cooling of the lower stratosphere of $0.8 \mathrm{~K}$ over two decades. Water vapour is also crucial for the chemical balance of the UTLS region through its role as a source of the hydroxyl radical (Esler et al., 2001), which is the main oxidant in the atmosphere. Therefore, a correct prediction of future climate requires a detailed knowledge of the water vapour distribution in the UTLS as well as the mechanisms regulating it.

Air enters the stratosphere mainly in the tropics and, therefore, processes at the tropical tropopause are of primary importance for our understanding of the water vapour distribution in the entire stratosphere. However, in the extratropics water vapour in the first few kilometres above the tropopause is largely controlled by extratropical troposphereto-stratosphere transport (TST) (Dessler et al., 1995; Hintsa et al., 1998). This transport is either quasi-isentropic in the vicinity of the jet streams (Hoerling et al., 1993), or diabatic inside of convection (Poulida et al., 1996). As a result, a mixing layer consisting of stratospheric and tropospheric air forms above the tropopause (Ray et al., 1999; Fischer et al., 2000). Satellite measurements of water vapour provide a global picture of its distribution in the lowermost stratosphere and are able to describe seasonal and interannual variations (see Chiou et al., 1997; Pan et al., 1997; Nedoluha et al., 2002; Randel et al., 2001, 2004, and references therein). However, since satellites have a limited spatial resolution, detailed process studies in the UTLS region can be based on in situ measurements only.

Published by Copernicus GmbH on behalf of the European Geosciences Union. 
Several water vapour in situ campaigns have been performed in the Arctic (Kelly et al., 1990; Ovarlez, 1991; Ovarlez and Ovarlez, 1994; Vömel et al., 1997), but only few have concentrated on the processes in the Arctic lowermost stratosphere. Murphy et al. (1990) and Schiller et al. (1999) detected ice saturation at the winter Arctic tropopause in aircraft observations. Pfister et al. (2003) used aircraft measurements during the SOLVE campaign 1999/2000 and estimated the vertical extent of the water vapour TST in the Arctic. Krebsbach et al. (2006) analysed the seasonality and variability of water vapour in the lowermost stratosphere within the broad latitude belt of $30^{\circ} \mathrm{N}$ to $80^{\circ} \mathrm{N}$ using aircraft measurements from the SPURT project.

This paper presents balloon borne water vapour measurements obtained during the Lapland Atmosphere-Biosphere Facility (LAPBIAT) Upper Tropospheric Lower Stratospheric Water Vapour Validation Project (LAUTLOSWAVVAP). This data set provides a suitable statistical basis to study the water vapour variability on synoptic time scales. Results related to polar vortex dynamics are discussed in Maturilli et al. (2006). This present study concentrates on the tropopause region and its main purpose is to present a detailed case study of transport processes contributing to the formation of a mixing layer above the tropopause in the winter Arctic. Attention is given to filamentation around upper level cut-off anticyclones since this process was linked to layers of enhanced water vapour in the lowermost stratosphere observed in several profiles during the campaign. The paper starts with a description of the data set and the tools used in this study. The distribution of water vapour in the lowermost stratosphere during the campaign is analysed in different vertical coordinates. Case studies demonstrate the effects of transport associated with filamentation of upperlevel cut-off anticyclones on the water vapour distribution. Cross-tropopause fluxes (CTF) are calculated to identify locations of stratosphere-troposphere exchange (STE) during the campaign. Contribution to STE of clear-air turbulence (CAT) diagnosed by a turbulence index is considered.

\section{Data sets and tools}

The LAUTLOS campaign took place from 29 January 2004 to 27 February 2004 at Sodankylä, Finland, $67.4^{\circ} \mathrm{N}, 26.6^{\circ} \mathrm{E}$, and was aimed at the intercomparison of lightweight balloon borne instruments (Suortti et al., 2007 ${ }^{1}$ ). For this purpose, several water vapour instruments were launched onboard the same balloon payload. Here, we use water vapour measurements obtained by the FLASH-B instrument, which provided the largest number of successful water vapour profiles in the lowermost stratosphere.

\footnotetext{
${ }^{1}$ Suortti, T. M., Miloshevich, L. M., Paukkunen, A., Leiterer, U., Kivi, R., Vömel, H., Yushkov, V., Ruppert, P., Neuber, R., and Kämpfer, N.: The LAUTLOS-WAVAP: Tropospheric comparisons, J. Atmos. Oceanic Technol., in review, 2007.
}

The FLASH-B instrument was developed at Central Aerological Observatory, Russia for balloon-borne water vapour measurements in the upper troposphere and stratosphere (Yushkov et al., 1998, 2000). The instrument is based on the fluorescent method. It uses the photodissociation of the $\mathrm{H}_{2} \mathrm{O}$ molecules that are exposed to vacuum ultraviolet radiation at a wavelength of $121.6 \mathrm{~nm}$ (Lyman-alpha hydrogen emission). The fluorescence of exited $\mathrm{OH}$ radicals in the range of $306-314 \mathrm{~nm}$ is detected by a photomultiplier run in photon counting mode. For stratospheric conditions the intensity of the fluorescent light sensed by the photomultiplier is directly proportional to the water vapour mixing ratio. The instrument is calibrated in the laboratory before the flight. The calibration is performed using the vacuum chamber where humidity is measured using commercial reference dew point hygrometer MBW 373L. The accuracy of the FLASH-B instrument is determined by the calibration error estimated as $4 \%$ in the $3-100$ ppmv range. The measurement precision is $5.5 \%$ calculated for $4 \mathrm{~s}$ integration time at stratospheric conditions. The total uncertainty of the measurement is less than $10 \%$ at the stratospheric mixing ratios greater than 3 ppmv. Altogether, 11 water vapour profiles have been obtained by the FLASH-B between 29 January 2004 and 27 February 2004. Only descent data, which avoid balloon contamination, are used here.

The NOAA/CMDL frost point hygrometer, which has the longest record of stratospheric water vapour observation at Boulder, CO (Oltmans et al., 2000), was used as reference instrument. This instrument uses two different sensitivity regimes: a lower setting, which allows the instrument to measure tropospheric water vapour, and a higher setting, better suited for stratospheric measurements. During LAUTLOS, the sensitivity change typically occurred in the lowermost stratosphere causing some data loss in this region (Vömel et al., 2007). The simultaneous measurements showed excellent agreement between FLASH-B and NOAA/CMDL instruments, with a mean deviation of $-2.4 \pm 3.1 \%(1 \sigma)$ for data between 15 and $25 \mathrm{~km}$ (Vömel et al., 2007) and the results are therefore independent of the choice of instrument.

Ozone was measured using ECC ozonesondes connected to the NOAA/CMDL frost point hygrometer flying on the same payload as FLASH-B. The ECC sensor is significantly slower than FLASH-B and to correct this sensor delay, the ozone signal in all profiles was advanced by $30 \mathrm{~s}$ as part of the analysis. This time lag corresponds to a sensor response time at a sensing solution temperature of about $278 \mathrm{~K}$ (Bethan et al., 1996). However, the effect of the relatively long response time is not only to delay the signal, but also to integrate it in space. This might be taken into account in the interpretation of the results that rely on the simultaneity of water vapour and ozone measurements, although the effect is not expected to be significant.

For back-trajectories and cross-tropopause flux estimations the trajectory model described by Lukyanov et al. (2003) is used. The trajectories are calculated in spherical 
Table 1. Listing of all soundings and tropopause altitudes used in Fig. 1.

\begin{tabular}{llllll}
\hline Date & $\begin{array}{l}\text { Time } \\
\text { (UT) }\end{array}$ & $\begin{array}{l}\text { Ozonesonde } \\
\text { available }\end{array}$ & $\begin{array}{l}\text { Thermal tropopause, } \\
\text { km }\end{array}$ & $\begin{array}{l}\text { Thermal tropopause, } \\
\text { K }\end{array}$ & $\begin{array}{l}\text { Dynamical (3.5 PVU) } \\
\text { tropopause, K }\end{array}$ \\
\hline 29 January 2004 & 17:30 & yes & 9.37 & 310.3 & 307.3 \\
30 January 2004 & $16: 53$ & yes & 8.84 & 301.4 & 307.6 \\
6 February 2004 & $19: 55$ & yes & 7.19 & 294.6 & 296.0 \\
11 February 2004 & $17: 34$ & yes & 9.99 & 321.3 & 310.6 \\
15 February 2004 & $17: 27$ & no & 9.30 & 316.6 & 306.8 \\
16 February 2004 & $17: 57$ & yes & 9.66 & 308.7 & 312.2 \\
17 February 2004 & $17: 45$ & yes & 8.95 & 320.4 & 303.3 \\
18 February 2004 & $17: 44$ & yes & 10.99 & 310.4 & 317.1 \\
23 February 2004 & $17: 46$ & yes & 8.66 & 305.7 & 314.2 \\
24 February 2004 & $17: 35$ & yes & 9.23 & 313.2 & 308.1 \\
25 February 2004 & $17: 37$ & no & 9.33 & & \\
\hline
\end{tabular}

a)

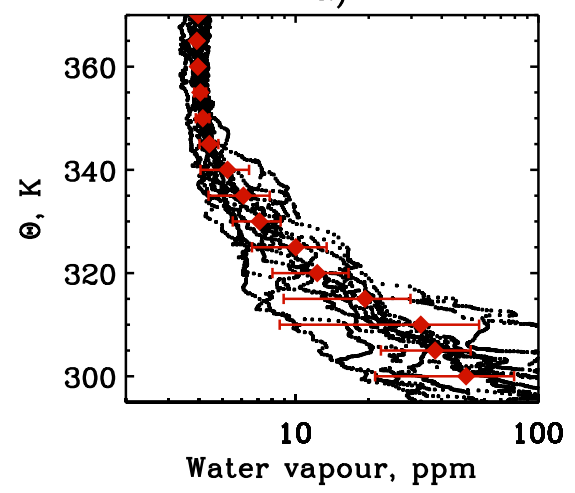

c)

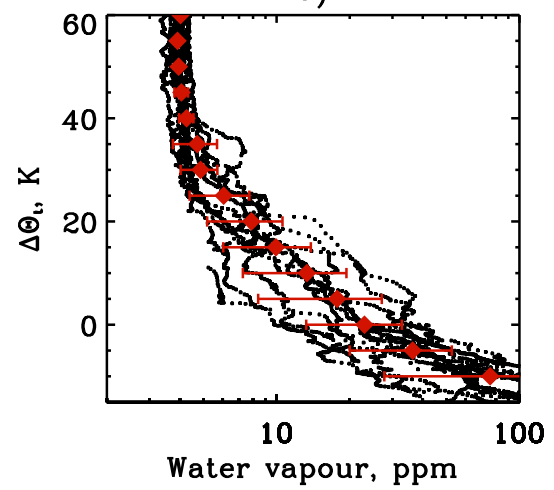

b)

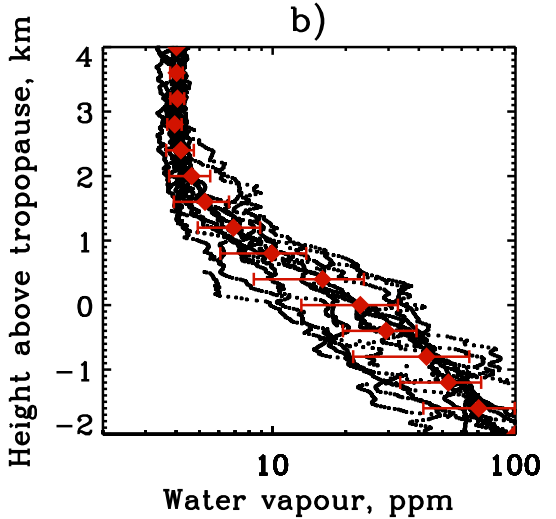

d)

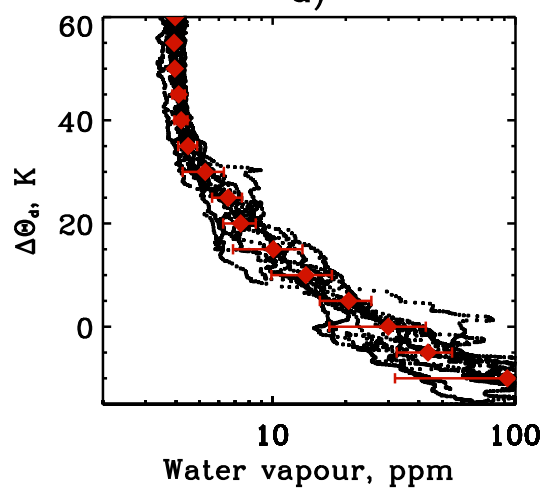

Fig. 1. WVMR as a function of (a) potential temperature, (b) height above the thermal tropopause, (c) $\Delta \theta$ above the thermal tropopause, (d) $\Delta \theta$ above the dynamical tropopause. WVMR averaged over all flights and one standard deviation are shown in red.

coordinates using the forth-order Runge-Kutta method with wind data linearly interpolated in time and space. The time step for calculations was set to $15 \mathrm{~min}$. To avoid inaccuracies near the poles, for latitudes exceeding $70^{\circ} \mathrm{N}$, the integration was conducted using Cartesian coordinates. Meteorological analyses are from the ECMWF model version T511L60. 3-D winds interpolated on 21 standard pressure levels with space resolution of $0.5^{\circ}$ latitude/longitude are used for the trajectory calculations. 


\section{Observations}

Table 1 provides information about all 11 profiles obtained during the LAUTLOS campaign. The distribution of water vapour in the tropopause region is shown in Fig. 1 as a function of different vertical coordinates. Figure 1a shows the water vapour mixing ratio (WVMR) as a function of potential temperature $(\theta)$. Studying potential temperature is not very useful for water vapour transport between the troposphere and the stratosphere, since it gives no information about the location of the tropopause. However, it is a natural way to put the data into context of the general circulation as well as to provide a suitable reference for comparison with other water vapour measurements. This figure shows that the highest level where noticeable flight-to-flight variability is observed is about $345 \mathrm{~K}$. Up to this level, WVMR exceeds, at times significantly, 6-7 ppmv, suggesting that air contains a significant fraction of tropospheric origin, i.e. air that has not passed through the tropical "cold trap" tropopause. Between $345 \mathrm{~K}$ and 360-380 K, WVMR shows values of about 4 ppmv with little flight-to-flight variability. Such low water vapour values suggest that the direct tropospheric contribution is not significant, though a small fraction of tropospheric origin might still be found at these levels. WVMR averaged over all flights is $4.1 \mathrm{ppmv}$ at $350 \mathrm{~K}$, whereas a minimum of $3.9 \mathrm{ppmv}$ is observed at $365 \mathrm{~K}$ (the hygropause level). Given the overall downward transport in the wintertime extratropical stratosphere, the small WVMR increase between $365 \mathrm{~K}$ and $350 \mathrm{~K}$ might be attributed to transport across the extratropical tropopause.

Estimates of the upper limit for penetration of tropospheric air found in the literature are close to our results. Measurements of reactive organic species (Scheeren et al., 2003) indicate that the fraction of tropospheric air in the mid latitude lowermost stratosphere during March 1997 approached zero at about $350 \mathrm{~K}$. Similar results were obtained by Chen (1995), who found very little TST in winter above $340 \mathrm{~K}$ using semi-Lagrangian transport model simulations. Also, Sprenger and Wernli (2003) showed a clear peak of winter TST in the layer 290-330 K.

More suitable for studies of STE are vertical coordinates that are centred at the tropopause. Figure $1 \mathrm{~b}$ shows water vapour as a function of height above the lapse rate tropopause (WMO definition). The flight-to-flight variability nearly disappears $2.5 \mathrm{~km}$ above the tropopause. This is slightly higher than the value of $1.8 \mathrm{~km}$ obtained from Arctic aircraft measurements in mid-winter 2000 (Pfister et al., 2003). Typical stratospheric WVMR values of less than 5 ppmv are reached already at $1-1.7 \mathrm{~km}$ above the thermal tropopause in 9 out of 11 profiles, while only two flights sampled enhanced WVMR higher than two kilometres above the tropopause. In all profiles WVMR continues to decrease with altitude up to the WVMR minimum, which is reached between 2.75 and $5 \mathrm{~km}$ above the tropopause. The average over all soundings shows a minimum of $3.9 \mathrm{ppmv}$ at $3 \mathrm{~km}$ above the tropopause.
Hoor et al. (2004) have shown that the CO distribution in the lowermost stratosphere correlates very well with the distance from the local dynamical tropopause expressed in the potential temperature $\left(\Delta \theta_{d}\right)$ and the scatter is significantly reduced compared to $\theta$ coordinate. Krebsbach et al. (2006) found a good correlation between $\Delta \theta_{d}$ and $\mathrm{H}_{2} \mathrm{O}$ and $\mathrm{O}_{3}$. Here, $\Delta \theta$ is calculated with respect to both the thermal $\left(\Delta \theta_{t}\right)$ and the dynamical $\left(\Delta \theta_{d}\right)$ tropopause. The distribution of the LAUTLOS water vapour measurements in $\Delta \theta_{t}$ coordinates calculated with respect to the thermal tropopause is shown in Fig. 1c. The flight-to-flight variability almost disappears at $\Delta \theta_{t}=30 \mathrm{~K}$, except for one profile which shows enhanced WVMR at $\Delta \theta_{t}=35 \mathrm{~K}$ above the thermal tropopause. However, comparing Fig. 1c and a shows that the scatter of the data is not reduced by the introduction of the $\Delta \theta_{t}$ coordinate and it is not evident that the water vapour distribution follows the shape of the thermal tropopause rather than the isentropic surfaces. Figure $1 \mathrm{~d}$ shows the water vapour distribution in $\Delta \theta_{d}$ coordinates calculated with respect to the dynamical tropopause which is obtained from the ECMWF potential vorticity $(\mathrm{PV})$ and potential temperature fields. To find $\theta$ at the dynamical tropopause, the vertical profiles of PV and $\theta$ were first constructed at the locations where the balloons crossed the thermal tropopause during descent. Then, $\theta$ was interpolated to the level of PV=3.5 PVU. Linear interpolation between model grid points was used both in horizontal and vertical direction. A value of 3.5 PVU was chosen because in a statistical sense it corresponds to the thermal tropopause in the extratropics (Hoerling et al., 1993). Using the $\Delta \theta_{d}$ coordinate noticeably reduces the WVMR scatter above the tropopause compared to Figs. 1a through c, with values gradually decreasing with height until stratospheric values are reached at about $\Delta \theta_{d}=30 \mathrm{~K}$. This is slightly higher than the value of $25 \mathrm{~K}$ found by Hoor et al. (2004) in CO observations. Note that Hoor et al. (2004) used the 2 PVU surface to define the dynamical tropopause.

Plotting water vapour against a tracer of stratospheric air is another possibility to assess mixing of stratospheric and tropospheric air. Figure 2 shows water vapour plotted against ozone. Note that only data from 9 flights are presented here, since ozone observations were not available on 15 February 2004 and 25 February 2004. While stratospheric air is characterized by high ozone and low water vapour, tropospheric air is characterized by high water vapour and low ozone. Mixing lines with intermediate values of ozone and water vapour are evident in Fig. 2 and can be formed only by irreversible mixing of tropospheric and stratospheric air (e.g. Hoor et al., 2002). The spread of water vapour values decreases noticeably between ozone values of 200 and $300 \mathrm{ppbv}$, and there is almost no variability above $400 \mathrm{ppbv}$. This is in agreement with values of 300-500 ppbv noted by Pfister et al. (2003) as an upper limit for the penetration of the tropospheric air into the stratosphere. As it was mentioned in Sect. 2, difference in the sensor response times introduces some uncertainty into these estimations although the effect 
is not expected to be significant. To determine the depth of the mixing layer, the data in Fig. 2 are colour-coded according to $\theta$. The mixing region extends up to $340-345 \mathrm{~K}$, which is close to the upper level of the flight-to-flight variability shown in Fig. 1a and is slightly higher than the value of $330 \mathrm{~K}$ found in aircraft observations of $\mathrm{O}_{3}$ and $\mathrm{CO}$ (Hoor et al., 2002). This difference may be related to the different tracers or the different measurement technique that was used. Interannual variability in tropopause dynamics cannot be excluded either.

In the tropopause region, a laminated structure in the vertical profiles of trace gases that have a strong gradient across the tropopause is usually indicative of recent crosstropopause transport. These cases are of particular interest in our study. Figure 3 a shows the profiles of water vapour and ozone obtained on 17 February 2004. Here, the pronounced WVMR maximum and the corresponding ozone minimum are centred at $330 \mathrm{~K}$, well above the local tropopause (see Table 1). This suggests recent transport of air with a large tropospheric fraction that has not yet been mixed with its surroundings. A similar event, but less pronounced and centred at $340 \mathrm{~K}$, was observed on 24 February 2004 (Fig. 3b). To investigate these events more thoroughly, the meteorological situation of the tropopause region is analysed and discussed in the next section.

\section{Meteorological situation}

The measurement period (late January to late February 2004), was characterised by high anticyclonic activity over the Northern Atlantic, which was linked to a negative phase of the Northern Atlantic Oscillation (NAO) index. At the same time the upper troposphere over Northern Scandinavia was mostly dominated by a long wave trough. Accordingly, the average thermal tropopause altitude at Sodankylä was lower than normal. Note that a low tropopause in the Arctic is one of the known characteristics of a low NAO index (Ambaum and Hoskins, 2002). Only for a short period (18 February-20 February 2004) did an upper-level anticyclone approach the station, and the thermal tropopause rose up to $12.5 \mathrm{~km}(166 \mathrm{hPa})$.

During February, several cut-off anticyclones developed over the eastern part of the Northern Atlantic following amplifications of the upper-level quasi-stationary ridge. One such cut-off anticyclone (hereafter A1) formed on 14 February 2004 just north of the British Isles. The development of the meteorological situation at the tropopause level can be seen in Fig. 4 which shows $330 \mathrm{~K}$ isentropic maps of water vapour obtained from ECMWF data.

The use of water vapour as a tracer for synoptic-scale transport in the UTLS has been utilized in a number of studies (Appenzeller and Davies, 1992; Gray et al., 1994; Beuermann et al., 2002). The water vapour distribution is able to reproduce large-scale systems, which appear on more tradi-

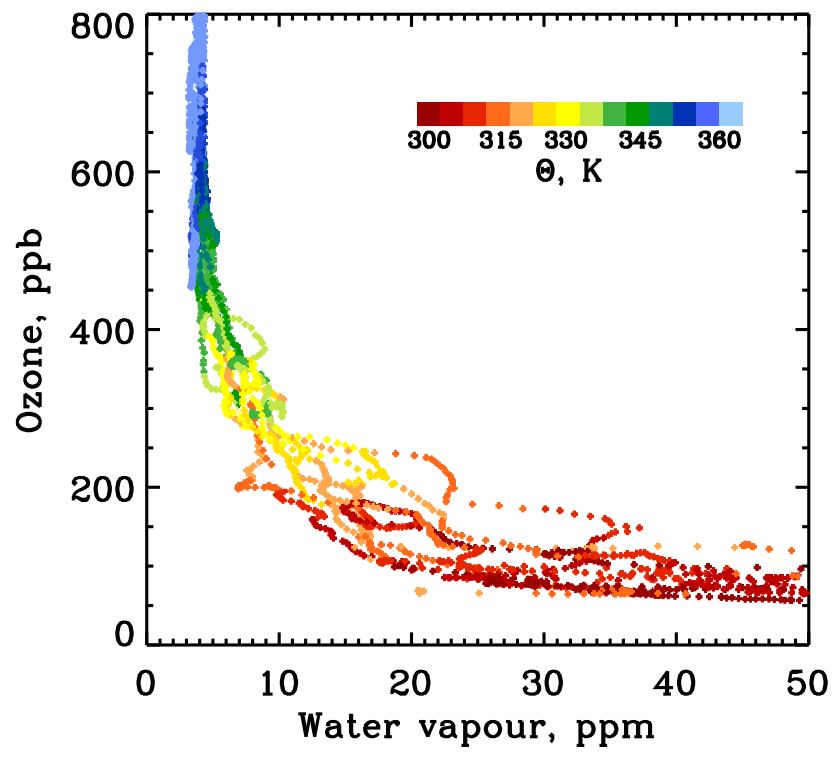

Fig. 2. Scatter plot of water vapour and ozone mixing ratios. The potential temperature is coded by colours.

tional PV maps, and gives a more detailed picture of processes on smaller scales. However humidity values in the upper troposphere are rather uncertain due to few and not always accurate observations. Differences between tracer properties of water vapour and PV were discussed by Simmons et al. (1999). First, PV, unlike water vapour, is subject to non advective processes like radiation. Second, water vapour in the ECMWF model is defined directly on the model grid, whereas PV is derived from dynamical fields represented spectrally. For these reasons, Simmons et al. (1999) suggested that water vapour provides a record of earlier synoptic events than PV does. It can be added that the vertical gradients of water vapour in the vertical range of interest is stronger than that of PV. Therefore, water vapour shows stronger gradients on isentropic surfaces due to differential advection.

Figure 4 shows that an area of higher water vapour (and lower PV) associated with A1 was advected southeastwardly for several days, before it finally dissipated over the Eastern Mediterranean. Note that the centre of A1 is drier than its flanks. This may be explained by saturation and subsequent dehydration that occurred around 12 February 2004 when temperatures at the $330 \mathrm{~K}$ isentropic level in the centre of the developing anticyclone were as cold as $200 \mathrm{~K}$ (saturation mixing ratio of about $7 \mathrm{ppmv}$ ). In the early stage of the development of A1, an area of enhanced water vapour became elongated meridionally north of A1 (Figs. 4b-d) and by 16 February 2004 a thin water vapour filament had formed. On 16 February 2004, 18:00 UTC this filament was located above Sodankylä (Fig. 4e). The sounding on 16 February 2004, 18:00 UTC sampled enhanced water vapour up to $335 \mathrm{~K}$ with a small local maximum of WVMR around $345 \mathrm{~K}$. 

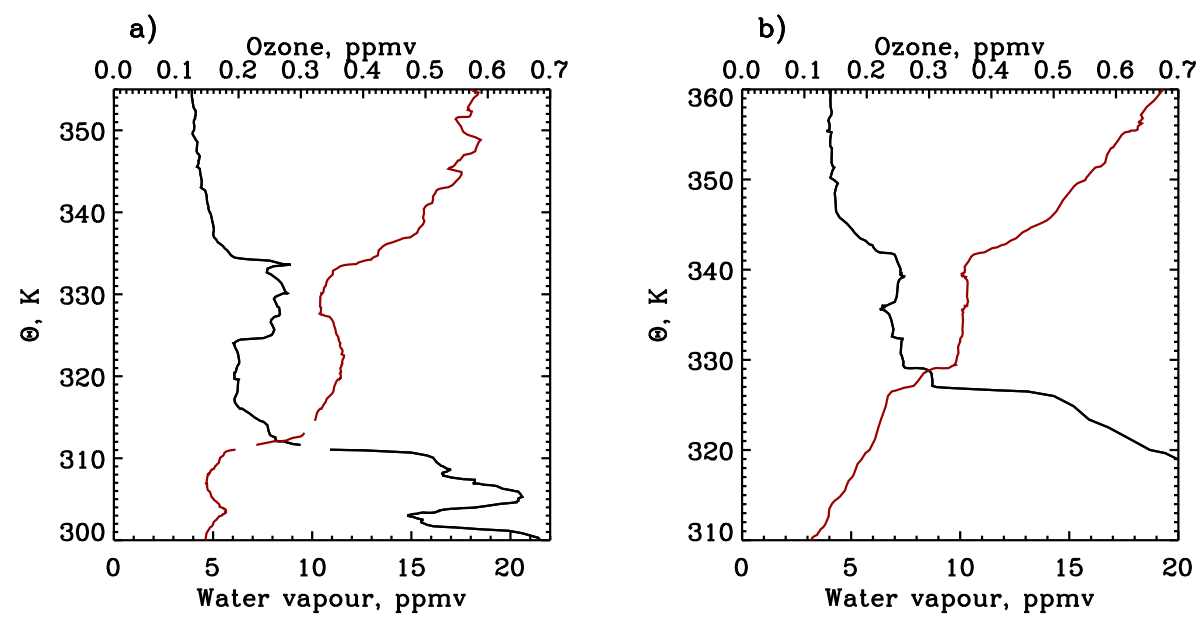

Fig. 3. Water vapour (black) and ozone (red) mixing ratios as a function of potential temperature on (a) 17 February 2004, 18:00 UTC, and (b) 24 February 2004, 18:00 UTC.

At $325 \mathrm{~K}, 16 \mathrm{ppmv}$ of water vapour were measured, which was the highest WVMR value at this level for the entire campaign. Growing wavelike perturbations along the filament finally led to its break up. However, remnants still appeared in the vicinity of the station on 17 February 2004, 18:00 UTC (Fig. 4g) when a layer of enhanced water vapour and reduced ozone mixing ratios was observed (Fig. 3a). During 16-17 February 2004, while the filament was located above the station, Northern Scandinavia was influenced by an upper-level trough and the thermal tropopause in Sodankylä was located at about $310 \mathrm{~K}$. To clearly identify the origin of this moist air, back trajectories were run starting 17 February 2004, 18:00 UTC at $330 \mathrm{~K}$ clustered around the station. As shown in Fig. 4, these trajectories followed the humid filament and on 14 February 2004 some of them crossed the dynamical tropopause at the southern flank of A1 (Fig. 4a). Since the trajectories are 3-D ones, they deviate with time from the $330 \mathrm{~K}$ isentropic surface. However only for the time step shown in Fig. 4a did the deviations become important. For this reason, the trajectories which were in the troposphere on 14 February 2004, 00:00 UTC are shown in red. Note that the trajectories crossed the tropopause before the filament developed. The role of the filament in this case was to transport the moist air deeper into the stratosphere away from the tropopause.

Analyses of water vapour isentropic maps reveal that the development of filaments similar to the one described above often accompany the development of cut-off anticyclones over the Northern Atlantic during January-February 2004. Figure 4h captures another filament on 18 February 2004, 18:00 UTC that stretched meridionally along approximately $30^{\circ} \mathrm{E}$, northeast of the area of low PV located over the Norwegian Sea. The corresponding anticyclone (hereafter A2) became cut-off over the Northern Atlantic on 17 February 2004 and was more intensive and stationary than A1. As A2 approached the station, a balloon sounding on 18 Febru- ary 2004, 18:00 UTC sampled a high thermal tropopause at $320 \mathrm{~K}$ and enhanced values of WVMR up to $345 \mathrm{~K}$.

An example of a humid filament at $340 \mathrm{~K}$ is shown in Fig. 5. The filament is curved above the Baltic Sea and Finland and stretched rather zonally between $15^{\circ} \mathrm{E}$ and $60^{\circ} \mathrm{E}$. The passage of this filament near Sodankylä on 24 February 2004, 18:00 UTC corresponded to the detection of the layer of enhanced water vapour and reduced ozone shown in Fig. 3b. Backward trajectories starting on this day suggest a very different situation. This air mass was involved in filamentation on 18 February 2004 during a poleward Rossby wave breaking event over the Aleutian Sea (not shown) and was subsequently advected for 6 days across North America and the Atlantic Ocean before being probed at Sodankylä.

The development of cut-off anticyclones, which from the dynamical point of view can be regarded as products of poleward Rossby-wave breaking, usually occurs in regions of diffluence over the eastern Atlantic and eastern Pacific. Contour advection simulations of these events revealed a structure richer than available in operational analyses at that time (Peters and Waugh, 1996), including the development of fine scale filaments similar to those shown here in the water vapour fields. Therefore, our case study analysis is useful even from a climatological perspective. Strong distortion of the tropopause associated with Rossby-wave breaking, both poleward and equatorward, is usually followed by non conservative processes such as diabatic heating and cooling or turbulent mixing (Holton et al., 1995). Low PV anomalies merge with the tropospheric jet a few days after their development and a large part of the tropospheric air contained in the cut-off anticyclones usually returns back to the troposphere. However, our observations demonstrate that processes during the lifecycle of cut-off anticyclones can lead to a noticeable distortion of the chemical composition in the lowermost stratosphere at high latitudes. 
a)

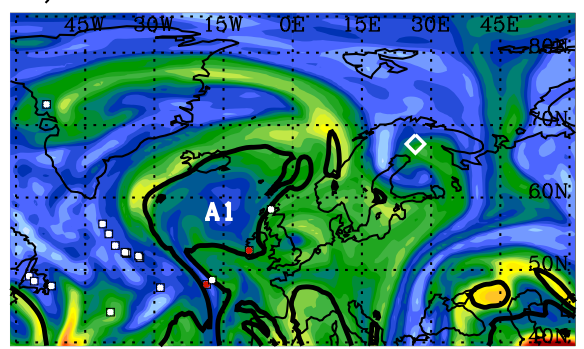

c)

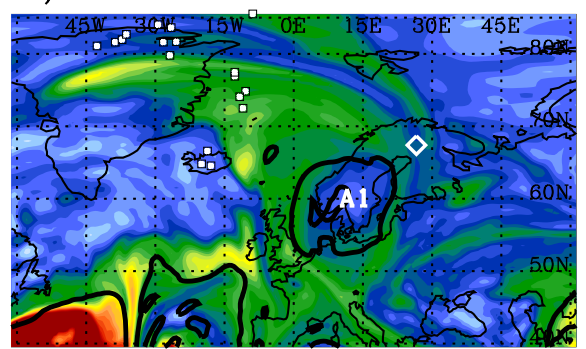

e)

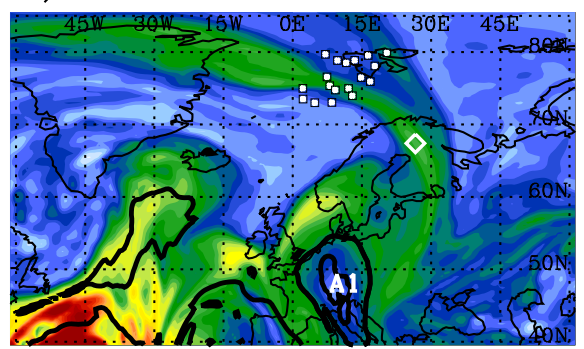

g)

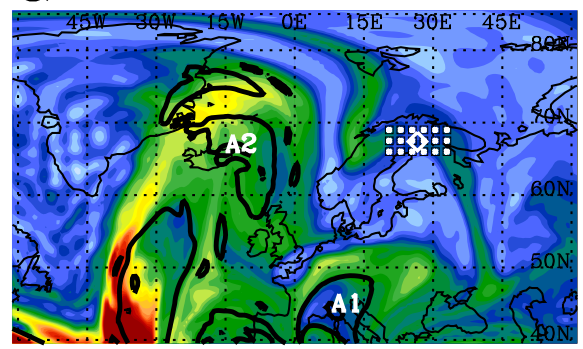

b)

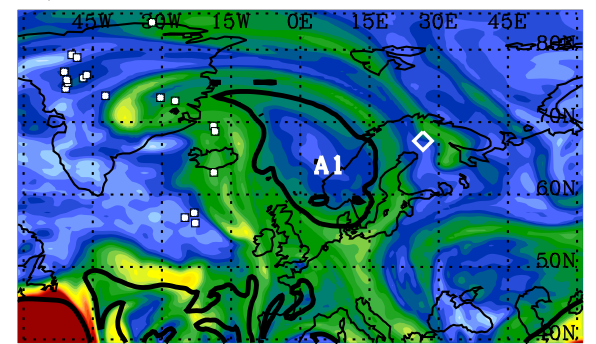

d)

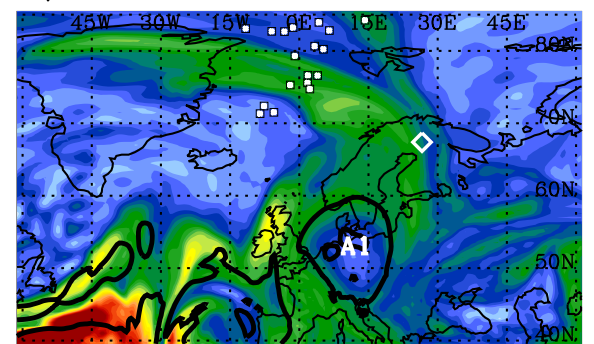

f)

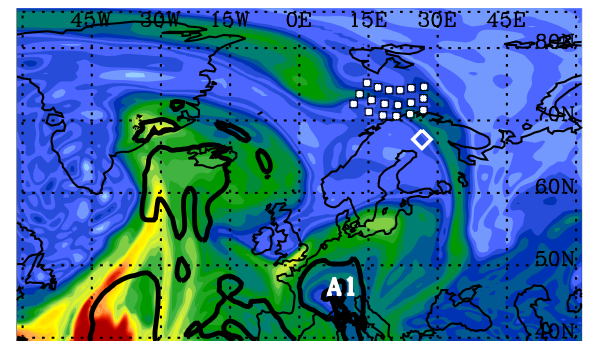

h)

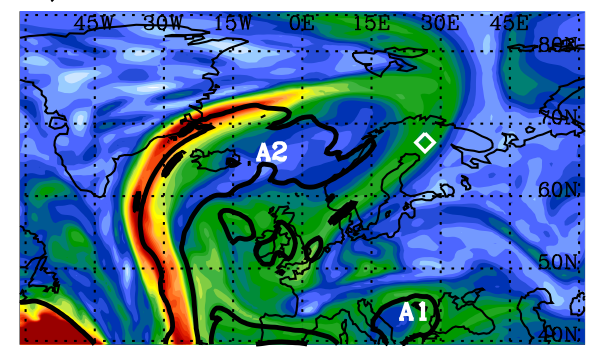

25

4

11

18

ppmv

Fig. 4. ECMWF WVMR maps at the $330 \mathrm{~K}$ isentropic surface on (a) 14 February 2004, 00:00 UTC, (b) 15 February 2004, 06:00 UTC, (c) 15 February 2004, 18:00 UTC, (d) 16 February 2004, 06:00 UTC, (e) 16 February 2004, 18:00 UTC, (f) 17 February 2004, 06:00 UTC, (g) 17 February 2004, 18:00 UTC and (h) 18 February 2004, 18:00 UTC. Black thick lines mark 3.5PVU contour of PV. White dots in (a-g) indicate the positions of the backward 3-D trajectories initiated on 17 February 2004, 18:00 UTC. The trajectories which were in the troposphere on 14 February 2004, 00:00 UTC are shown in red in (a). The white diamond indicates the location of Sodankyla. A1 and A2 indicate the positions of the anticyclones discussed in the text.

\section{Cross-tropopause flux associated with cut-off anticy- clones}

It was shown in the previous section that the crosstropopause transport of water vapour occurred at the flanks of the cut-off anticyclone. We now look in more detail on where STE occurred during the event and try to link it to the physical processes. Two primary physical processes are responsible for changes in PV (and therefore for STE), smallscale turbulence and diabatic heating. Only the effect of turbulence is considered in the following. In anticyclones, clear-air turbulence (CAT) can form in the region of strong 

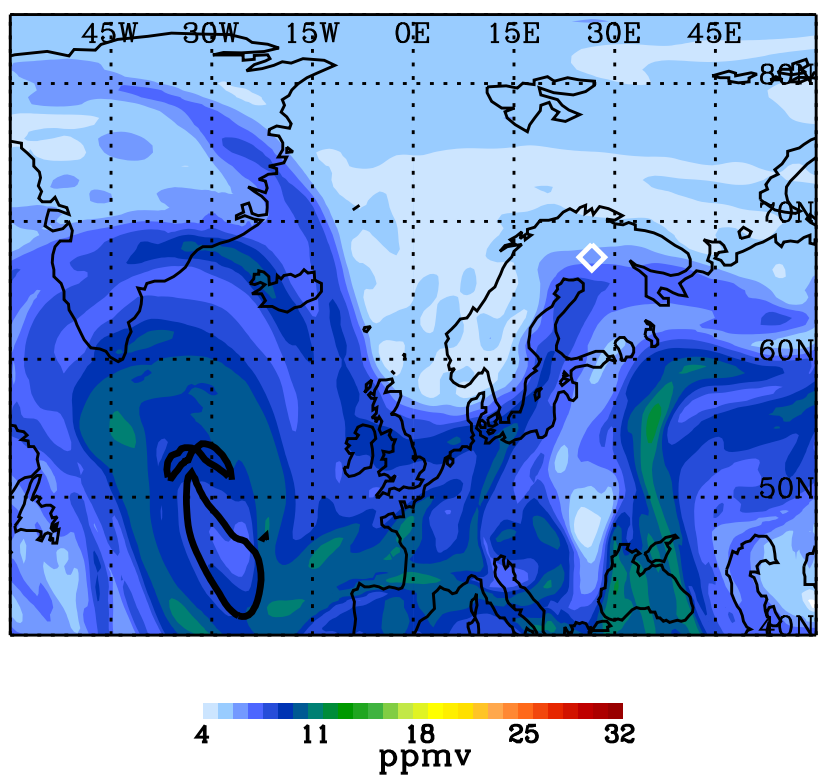

Fig. 5. ECMWF WVMR map at the $340 \mathrm{~K}$ isentropic surface on 24 February 2004, 18:00 UTC. Black thick lines mark 3.5 PVU contours of PV. The white diamond indicates the location of Sodankylä.

winds surrounding the anticyclone. CAT, whose importance for STE was recognized long ago (Shapiro, 1980), can be diagnosed using a turbulence index (TI) (Ellrod and Knapp, 1992):

$\mathrm{TI}=\left[\left(\frac{\partial u}{\partial x}-\frac{\partial v}{\partial y}\right)^{2}+\left(\frac{\partial v}{\partial x}+\frac{\partial u}{\partial y}\right)^{2}\right]^{0.5} \frac{\partial|\boldsymbol{V}|}{\partial z}$,

where $u$ and $v$ are the zonal and the meridional components of the wind; $|\boldsymbol{V}|$ is the absolute value of the wind; $x, y$, and $z$ are the horizontal and the vertical coordinates. The probability of the occurrence of CAT is higher where TI is higher. The unit of TI is $10^{-7} \mathrm{~s}^{-2}$.

First, we relate PV changes along the trajectories with TI values. Several backward trajectories started on 17 February 2004, 18:00 UTC at $330 \mathrm{~K}$ crossed the dynamical tropopause during 5 days of the calculations. The largest number of trajectories crossed the tropopause on 14 February 2004 between 00:00 UTC and 06:00 UTC. Figure 6 shows the initial positions and the end points of these trajectories on 14 February 2004, 06:00 UTC, immediately after they crossed the tropopause. Not only trajectories that start in the vicinity of Sodankylä but also those that start elsewhere in the filament are shown here. High TI values in the vicinity of the end points suggest a high probability of CAT. Note that, while $\mathrm{TI}$ is plotted at $330 \mathrm{~K}$, the end points are located on different levels since the trajectories are three-dimensional ones. Figure 7 shows the PV and the TI values along the trajectories. It is seen that the TI values peak on 14 February 2004, 06:00 UTC when the PV values change from tropospheric to stratospheric.
The above analysis shows that TST occurs along the flanks of the anticyclone and also suggests a link between TST and CAT. To verify these results we now consider STE and CAT over the Northern Atlantic and Europe during the period of campaign. There are several studies of STE in the extratropics (Hoerling et al., 1993; Siegmund et al., 1996; Wirth and Egger, 1999; Kowol-Santen et al., 2000; Sigmond et al., 2000; Wernli and Bourqui, 2002), which are based on analyzed winds and focused on the estimation of local instantaneous CTF. These studies applied both Eulerian methods based on Wei's formula (Wei, 1987) and Lagrangian methods based on trajectory calculations. Siegmund et al. (1996) found that for accurate estimates of the local and instantaneous CTF, the spatial and temporal resolution of the analyzed data should be at least $1^{\circ} \times 1^{\circ}$ and $6 \mathrm{~h}$, respectively. In the present study, the transport of air through the tropopause is investigated using a trajectory model and analyzed winds from the ECMWF model version T511L60 (horizontal resolution $0.5^{\circ} \times 0.5^{\circ}$ and temporal resolution $6 \mathrm{~h}$ ). The method used here is based on the formula by Wei with PV as a vertical coordinate. The CTF is defined as:

$F=-\frac{1}{g} \frac{\partial p}{\partial \mathrm{PV}} \frac{d \mathrm{PV}}{d t}$,

where $p$ is the pressure and $g$ is the acceleration due to gravity. The unit of $F$ is $\mathrm{kg} \mathrm{m}^{-2} \mathrm{~s}^{-1}$. Following Sigmond et al. (2000) the material derivative of PV is estimated using a Lagrangian approach. $6 \mathrm{~h}$ forward and backward trajectories are initiated at each grid point and PV values at the end points of trajectories are used for the estimation of the PV tendency. The partial derivative $\frac{\partial p}{\partial \mathrm{PV}}$ is calculated on each grid point by using pressure values on PV levels adjacent to the tropopause. Due to the combination of calculations on the grid and along the trajectories this method can be considered as "semi-Lagrangian". Fluxes are calculated through the 3.5 PVU isosurface of PV used to define the dynamical tropopause. We concentrate our analysis on the period from 14 to 19 February 2004, which largely covers the lifetime of A1.

Examples of CTF and TI fields for selected dates are shown in Fig. 8. It is seen that the strongest fluxes (upward and downward) are concentrated in the tropopause-slope region, i.e. along the potential temperature contours in Fig. 8. Note that the concentration of potential temperature contours also marks regions of strong winds. On 14 February 2004, 18:00 UTC (Fig. 8a), the jet stream bends around A1 centred east of Iceland. On 15 February 2004 (Fig. 8c), the jet stream moves with A1 towards Scandinavia, weakening at the same time. By 17 February 2004, when A2 starts forming over the Northern Atlantic, the jet stream intensifies over the Greenland Sea (Fig. 8e). It is also seen that the strongest fluxes often coincide with areas of strong turbulence near the jet stream (Figs. 8b, d, f). This subjective conclusion is supported by the correlation between the area-integrated CTF and TI. Figure 9 shows a time series of the area-integrated 
a)

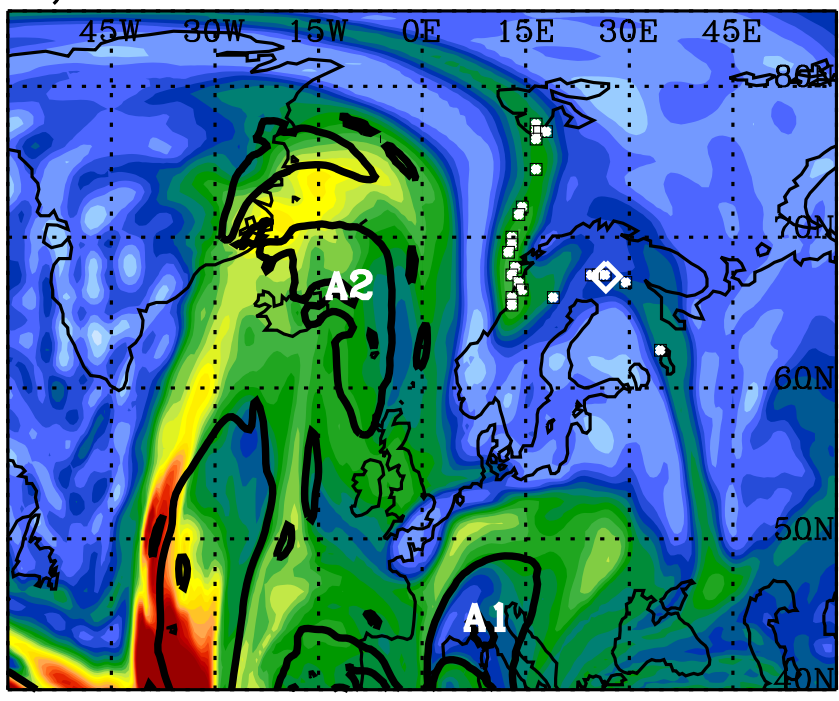

b)

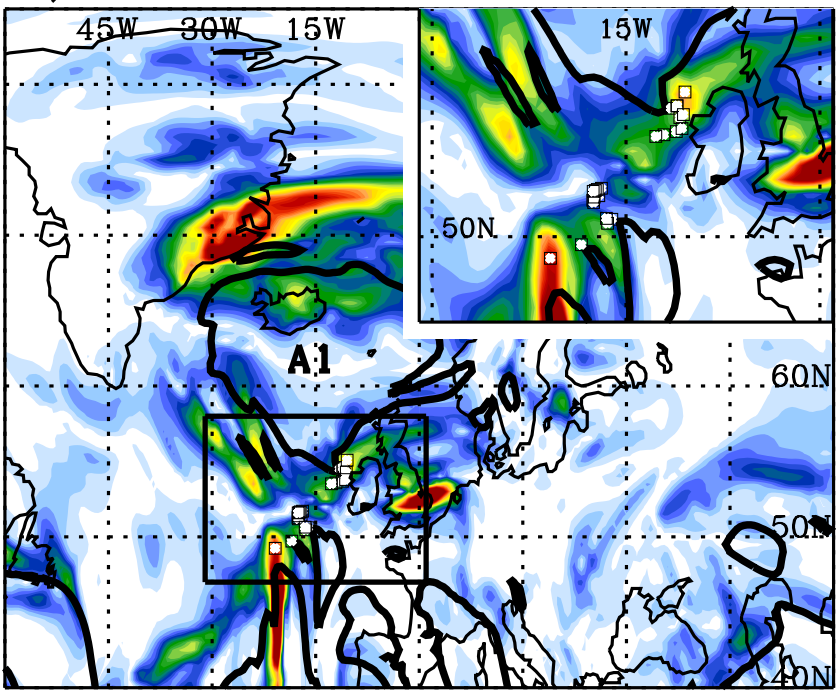

Fig. 6. (a) ECMWF WVMR map at the $330 \mathrm{~K}$ isentropic surface on 17 February 2004, 18:00; (b) TI values at the $330 \mathrm{~K}$ isentropic surface on 14 February 2004, 06:00 UTC. Black thick lines mark 3.5 PVU contour of PV. White dots indicate the positions of the backward 3-D trajectories initiated on 17 February 2004, 18:00 UTC at $330 \mathrm{~K}$. The trajectories which crossed the dynamical tropopause on 14 February 2004 between 00:00 UTC and 06:00 UTC are shown. The white diamond indicates the location of Sodankyla. A1 and A2 indicate the positions of the anticyclones discussed in the text. Region inside the black rectangle in (b) is enlarged in the inset.

upward and downward CTF together with the TI values for the whole period calculated in 6-h time steps. All quantities are integrated over the area between $50^{\circ} \mathrm{W}$ and $60^{\circ} \mathrm{E}$ longitudes and between $50^{\circ} \mathrm{N}$ and $85^{\circ} \mathrm{N}$ latitudes. It is seen that the minimum of the area-averaged TI value around 16 February 2004 corresponds to minima in both upward and downward fluxes. The increase of the TI after 18 February 2004, associated with the intensification of the jet stream around A2, coincides with an increase in both fluxes. Absolute values of the correlation coefficient between the TI and the upward and downward fluxes are 0.48 and 0.64 , respectively. These results are statistically significant at the $95 \%$ confidence level and suggest that the turbulence at the flanks of cut-off anticyclones can be important for the transport across the tropopause. However, while the correlation between the TI values and the downward fluxes is fairly insensitive to changes in the area of integration, the correlation between the TI values and the upward fluxes changes significantly. For example, moving the southern border of the integration area northward improves the correlation while extending the area southward by some ten degrees decreases the correlation coefficient to insignificant values. This suggests that other processes than CAT might be more significant for the upward transport. Studies involving radiative calculations are required in order to achieve a solid conclusion on contribution of different processes to STE.

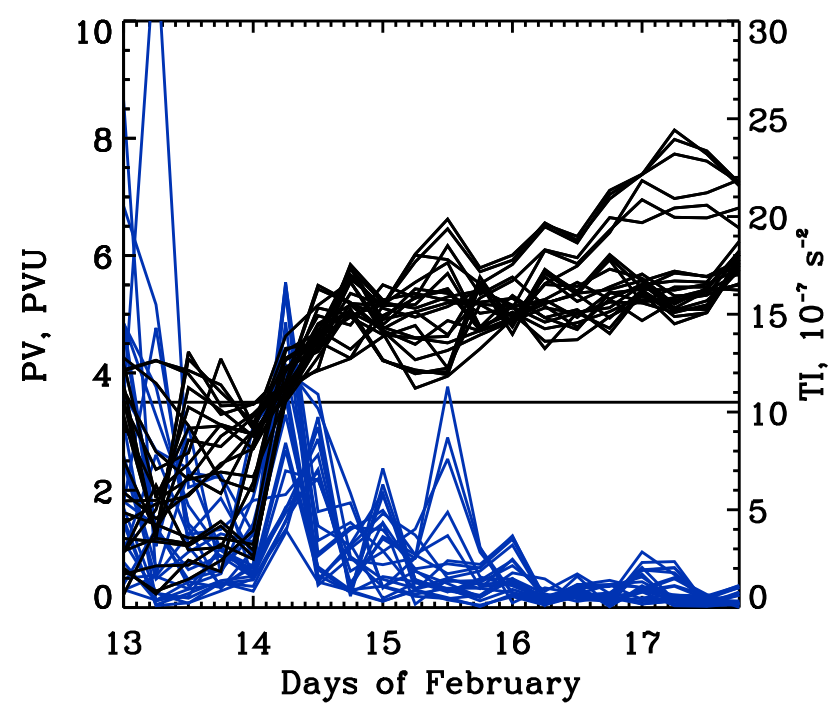

Fig. 7. PV and TI values along the trajectories shown in Fig. 6. PV is black and TI is blue. The 3.5 PVU level defines the dynamical tropopause.

Significant fluxes are also found away from the jet stream, where the TI values are significantly weaker. An example is given in Fig. 8e for 17 February 2004, 12:00 UTC. Areas 
a)

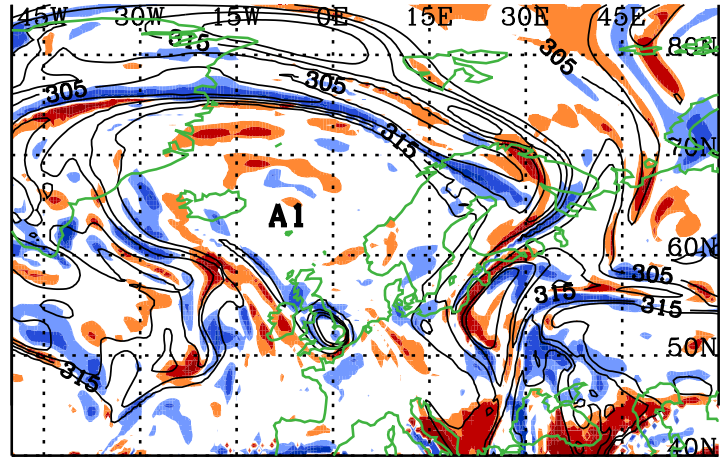

c)

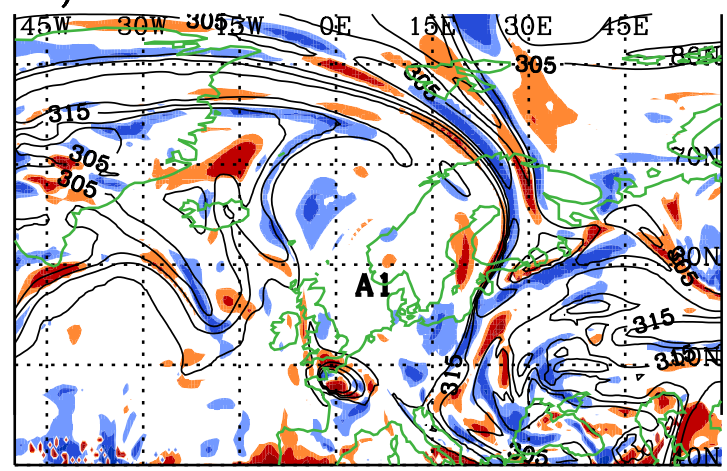

e)
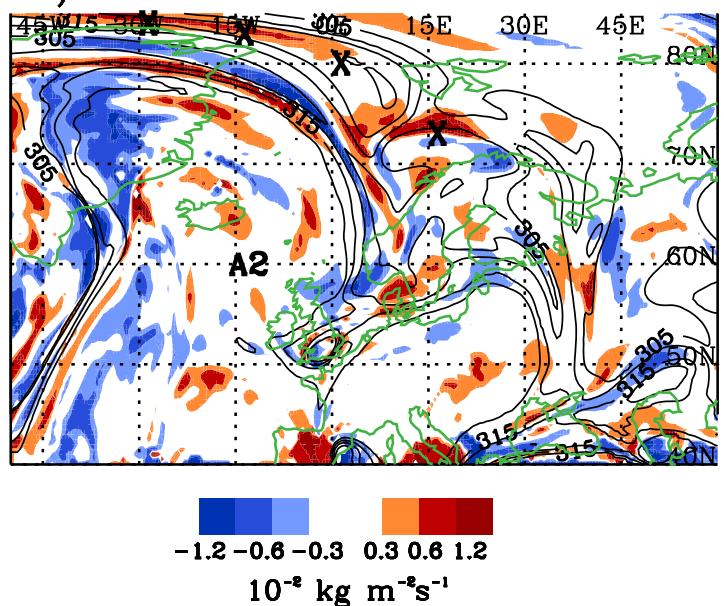

b)

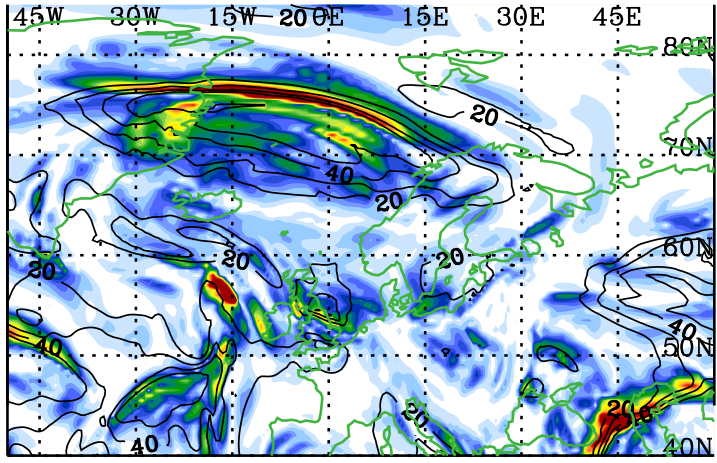

d)

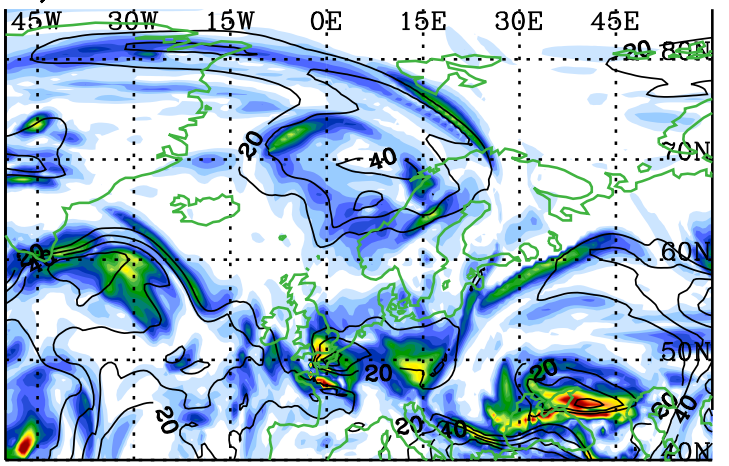

f)
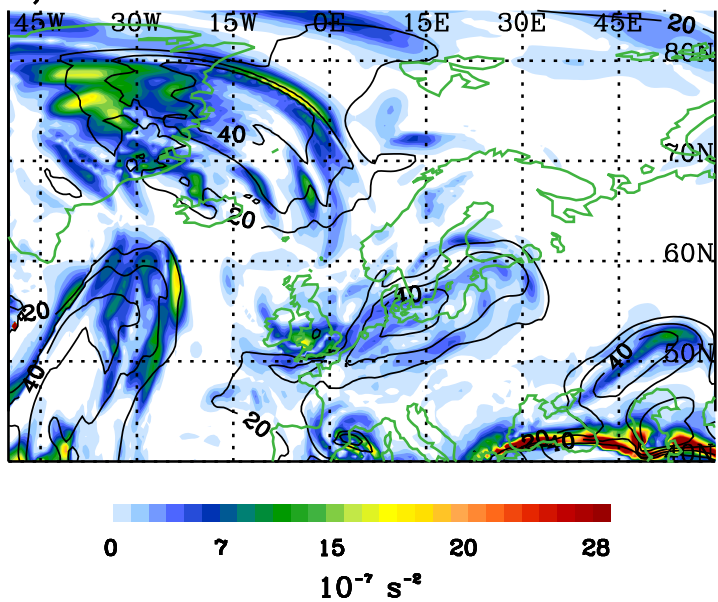

Fig. 8. (a), (c), (e) CTF across 3.5 PVU isosurface of PV and (b), (d), (f) TI values at 3.5 PVU isosurface on (a, b) 14 February 2004, 18:00 UTC, (c, d) 15 February 2004, 18:00 UTC, and (e, f) 17 February 2004, 12:00 UTC. Black solid lines are (a, c, e) potential temperature contours $(\mathrm{K})$ and $(\mathrm{b}, \mathrm{d}, \mathrm{f})$ wind speed contours $(\mathrm{m} / \mathrm{s})$. A1 and A2 indicate the positions of the anticyclones. The crosses indicate the position of the filament discussed in the text.

of strong upward fluxes are seen adjacent to remnants of the filament (i.e. areas of higher potential temperature) south of Spitsbergen and north of Greenland. A noticeable decrease in filament size, which is observed at the same time, suggests that these fluxes are associated with the decay of the filament.

The fluxes shown in Fig. 9 have been integrated over the whole domain including areas not coloured in Fig. 8, where absolute values of the fluxes are small (less than $\left.3 \times 10^{-2} \mathrm{~kg} \mathrm{~m}^{-2} \mathrm{~s}^{-1}\right)$. It is therefore necessary to comment on the contribution and significance of these "weak" fluxes. During the study period "weak" fluxes contribute on average $29 \%$ and $36 \%$ to the analysed upward and downward fluxes integrated over the whole domain and do not reveal any noticeable response to changes in the meteorological situation. 
Though one can argue that this is a significant contribution to the quantitative estimations shown in Fig. 9, our conclusions concerning the regions of a prime importance for the STE remain nevertheless valid. A part of the "weak" fluxes can be attributed to numerical noise; however, there is no clear way to choose a threshold for a separation between real transport and noise (see Gettelman and Sobel, 2000).

Finally we note that results similar to those discussed in this section are found when forecast data are used instead of analysis.

\section{Conclusions}

Balloon-borne water vapour measurements obtained during the LAUTLOS campaign in January-February 2004 at Sodankylä, Finland, $67^{\circ} \mathrm{N}$ were used to analyse the water vapour distribution in the wintertime Arctic lowermost stratosphere and to identify mechanisms that are important for the formation of the observed distribution. A significant variability of water vapour due to synoptic processes at the tropopause was observed up to $345 \mathrm{~K}$ with much smaller variability in the upper part of the lowermost stratosphere (up to the stratospheric polar vortex). The layer above the tropopause that is significantly influenced by transport through the extratropical tropopause is approximately $2.5 \mathrm{~km}$ (or $30 \mathrm{~K}$ in the potential temperature) thick and follows the shape of the dynamical rather than the thermal tropopause. Cross-correlation analyses of ozone and water vapour confirm that this layer contains a mixture of stratospheric and tropospheric air. Water vapour concentrations continue to decrease up to about $365 \mathrm{~K}$ ( $3-5 \mathrm{~km}$ above the thermal tropopause), the level of the hygropause, and an influence of the extratropical troposphere up to the hygropause cannot be excluded. Indeed, there are observational evidences for transport of tropospheric ozone up to $360-380 \mathrm{~K}$ in winter (Vaughan and Timmis, 1998).

The distribution of water vapour up to $345 \mathrm{~K}$ was strongly influenced by transport processes associated with cut-off anticyclones which were active during the campaign over the Northern Atlantic. Filaments, which quite often accompanied development of the cut-off anticyclones during late winter 2004, were sampled by balloons as layers of enhanced water vapour and reduced ozone centred at $330-340 \mathrm{~K}$. The filaments were resolved by the ECMWF analyses. This demonstrates that the ECMWF model can successfully reproduce, at least qualitatively, details of the water vapour distribution in the lowermost stratosphere. Analysis of one such case shows that the air contained in the layer had been transported through the tropopause before the filament developed. The role of the filament was to transport the air enriched with water vapour deeper into the stratosphere.

Calculations of the CTF over the Northern Atlantic and Europe show that two-way STE occurs mainly in the tropopause-slope regions i.e. regions where isentropic sur-

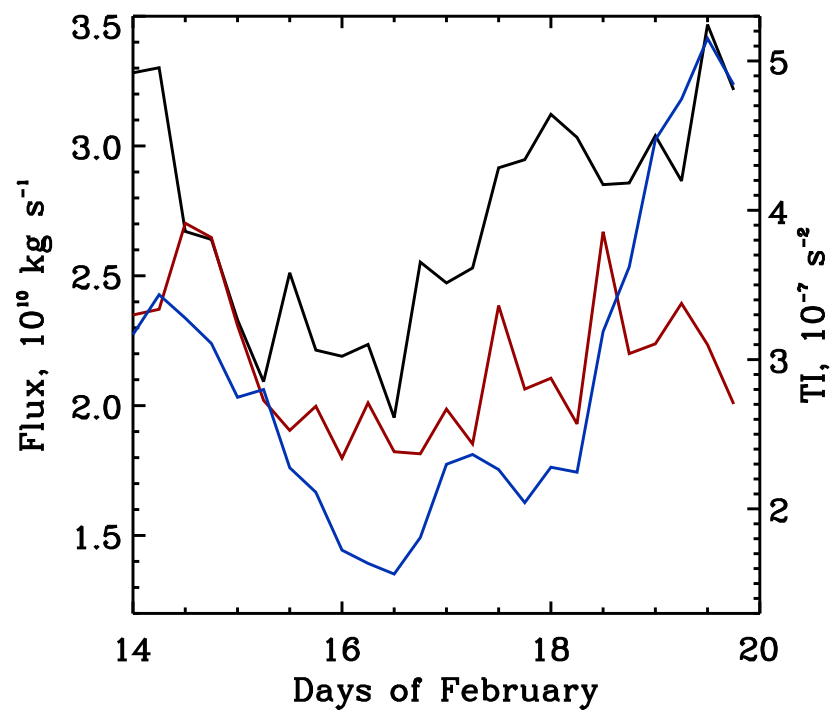

Fig. 9. Time series of the TI values at 3.5 PVU isosurface and absolute values of downward and upward CTF averaged over the domain $50^{\circ} \mathrm{W}-60^{\circ} \mathrm{E}$ and $50^{\circ} \mathrm{N}-85^{\circ} \mathrm{N}$. Downward CTF are black, upward CTF are red, TI is blue.

faces cross the dynamical tropopause. The strongest CTF of both signs were observed around cut-off anticyclones. This suggests that a part of the STE there is reversible: a particle can easily cross the tropopause up and down. Filamentation involves the air above the tropopause and the air is transported away from the region where it can easily return to the troposphere, hence more likely contributing to the irreversible exchange and formation of the mixing layer.

Since surroundings of anticyclones are a region where CAT can develop, an attempt was made to connect STE with CAT. Trajectory analysis shows that the moist air mass sampled above the tropopause in one of the soundings crossed the tropopause in a region characterised by high TI, which suggests a high probability of CAT there. This result evidences that CAT plays a role in the TST and is in line with Traub and Lelieveld (2003), who have found a connection between the upward flux and the CAT, associated with the monsoon circulation over the eastern Mediterranean in summer. However, while statistically significant correlation is found between the downward CTF and the TI values over the Northern Atlantic and Europe during the period of campaign, the correlation between the upward fluxes and the TI is weak. Further studies involving radiative calculations are required before a solid conclusion on the relative importance of different processes for STE can be achieved.

Acknowledgements. The LAUTLOS campaign was funded by the EU under projects LAPBIAT and Cost 723. We thank the entire LAUTLOS team for their excellent work. A. Karpechko, E. Kyrö, and R. Kivi acknowledge support from the Finnish Academy under projects FAPOR and FARPOCC. A. Lukyanov, S. Khaikin, and L. Korshunov acknowledge support from the International Science 
\& Technology Center (ISTC) under projects \#3093 and \#3095. We would like to thank ECMWF for providing meteorological data. We also would like to thank the reviewers and the editor for helpful comments. Calculations of PV and interpolations of the data on the isentropic levels were done using codes developed by H. Wernli.

Edited by: H. Wernli

\section{References}

Ambaum, M. H. and Hoskins, B. J.: The NAO tropospherestratosphere connection, J. Climate, 15, 1969-1978, 2002.

Appenzeller, C. and Davies, H. C.: Structure of stratospheric intrusions into the troposphere, Nature, 358, 570-572, 1992.

Bethan, S., Vaughan, G., and Reid, S. J.: A comparison of ozone and thermal tropopause heights and the impact of tropopause definition on quantifying the ozone content of the tropopause, Quart. J. Roy. Meteorol. Soc., 122, 929-944, 1996.

Beuermann, J., Konopka, P., Brunner, D., Bujok, O., Günther, O., McKenna, D. S., Lelieveld, J., Muller, R., and Schiller, C.: Highresolution measurements and simulation of stratospheric and tropospheric intrusions in the vicinity of the polar jet stream, Geophys. Res. Lett., 29, 1577, doi:10.29/2001GL014162, 2002.

Chen, P.: Isentropic cross-tropopause mass exchange in the extratropics, J. Geophys. Res., 100(D8), 16661-16673, 1995.

Chiou, E. W., McCormick, M. P., and Chu, W. P.: Global water vapor distribution in the stratosphere and upper troposphere derived from 5.5 years of SAGE II observations (1986-1991), J. Geophys. Res., 102(D15), 19 105-19118, 1997.

Dessler, A. E., Hintsa, E. J., Weinstock, E. M., Anderson, J. G., and Chan, K. R.: Mechanisms controlling water vapour in the lower stratosphere: A tale of two stratospheres, J. Geophys. Res., 100(D11), 23 167-23 172, 1995.

Ellrod, G. P. and Knapp, D. I.: An objective clear-air turbulence forecasting technique: Verification and operational use, Wea. Forecasting, 7, 150-165, 1992.

Esler J. G., Tan, D. G. H., Haynes, P. H., Evans, M. J., Law, K. S., Plantevin, P.-H., and Pyle, J. A.: Stratosphere-troposphere exchange: Chemical sensitivity to mixing, J. Geophys. Res., 106(D5), 4717-4731, 2001.

Fischer H., Wienhold, F.-G., Hoor, P., Bujock, O., Schiller, C., Siegmund, P., Ambaum, M., Scheeren, H. A., and Lelieveld, J.: Tracer correlations in the northern high latitude lowermost stratosphere: Influence of cross-tropopause mass exchange, Geophys. Res. Lett., 27, 97-100, 2000.

Forster, P. M. de F. and Shine, K. P.: Assessing the climate impact of trends in stratospheric water vapor, Geophys. Res. Lett., 29(6), 1086, doi:10.1029/2001GL01390, 2002.

Gettelman, A. and Sobel, A. H.: Direct diagnoses of stratospheretroposphere exchange, J. Atmos. Sci., 57, 3-16, 2000.

Gray, L. J., Bithell, M., and Cox, B. D.: The role of specifichumidity fields in the diagnosis of stratosphere troposphere exchange, Geophys. Res. Lett., 21, 2103-2106, 1994.

Hintsa, E. J., Boerling, K. A., Weinstock, E. M., Anderson, J. G., Gary, B. L., Pfister, L., Daube, B. C., Wofsy, S. C., Loewenstein, M., Podolske, J. R., Margitan, J. J., and Bui, T. P.: Troposphere-to-stratosphere transport in the lowermost stratosphere from measurements of $\mathrm{H}_{2} \mathrm{O}, \mathrm{CO}_{2}, \mathrm{~N}_{2} \mathrm{O}$, and $\mathrm{O}_{3}$, Geophys. Res. Lett., 25, 2655-2658, 1998.
Hoerling, M. P., Schaack, T. K., and Lenzen, A. J.: A global analysis of Stratospheric-tropospheric exchange during Northern Winter, Mon. Wea. Rev., 121, 162-172, 1993.

Holton, J., Haynes, P., McIntyre, M., Douglass, A., Rood, R., and Pfister, L.: Stratosphere-troposphere exchange, Rev. Geophys., 33, 403-440, 1995.

Hoor, P., Fischer, H., Lange, L., Lelieveld, J., and Brunner, D.: Seasonal variations of a mixing layer in the lowermost stratosphere as identified by the CO-O3 correlation from in situ measurements, J. Geophys. Res., 107, 4044, doi:10.1029/2000JD000289, 2002.

Hoor, P., Gurk, C., Brunner, D., Hegglin, M. I., Wernli, H., and Fischer, H.: Seasonality and extent of extratropical TST derived from in-situ CO measurements during SPURT, Atmos. Chem. Phys., 4, 1427-1442, 2004, http://www.atmos-chem-phys.net/4/1427/2004/.

Kelly, K. K., Tuck, A. F, Heidt, L. E., Loewenstein, M., Podolske, J. R., Strahan, S. E., and Vedder, J. F.: A comparison of ER-2 measurements of stratospheric water vapour between the 1987 Antarctic and 1989 Arctic airborne missions, Geophys. Res. Lett., 17(4), 465-468, 1990.

Kowol-Santen, J., Elbern, H., and Ebel, A.: Estimation of crosstropopause airmass fluxes at midlatitudes: Comparison of different numerical methods and meteorological situations, Mon. Wea. Rev., 128, 4045-4057, 2000.

Krebsbach, M., Schiller, C., Brunner, D., Günther, G., Hegglin, M. I., Mottaghy, D., Riese, M., Spelten, N., and Wernli, H.: Seasonal cycles and variability of $\mathrm{O} 3$ and $\mathrm{H} 2 \mathrm{O}$ in the UT/LMS during SPURT, Atmos. Chem. Phys., 6, 109-125, 2006, http://www.atmos-chem-phys.net/6/109/2006/.

Lukyanov, A., Nakane, H., and Yushkov, V.: Lagrangian estimations of ozone loss in the core and edge region of the arctic polar vortex 1995/1996: Model results and observations, J. Atmos. Chem., 44(2), 191-210, 2003.

Maturilli, M., Fierli, F., Yushkov, V., Lukyanov, A., Khaykin, S., and Hauchecorne, A., StratosphericWater Vapour in the Vicinity of the Arctic Polar Vortex, Ann. Geophys., 24, 1511-1521, 2006 , http://www.ann-geophys.net/24/1511/2006/.

Murphy, D. M., Kelly, K. K., Tuck, A. F., and Proffitt, M. H.: Ice saturation at the tropopause observed from ER-2 aircraft, Geophys. Res. Lett., 17, 353-356, 1990.

Nedoluha, G. E., Bevilacqua, R. M., Hoppel, K. W., Lumpe, J. D., and Smit, H.: Polar Ozone and Aerosol Measurement III measurements of water vapor in the upper troposphere and lowermost stratosphere, J. Geophys. Res., 107(D10), 4103, doi:10.1029/2001JD000793, 2002.

Oltmans, S. J., Vömel, H., Hofmann, D. J., Rosenlof, K. H., and Kley, D.: The increase in stratospheric water vapor from balloonborne frost-point hygrometer measurements at Washington, D. C., and Boulder, Colorado, Geophys. Res. Lett., 21, 34533456, 2000.

Ovarlez, J.: Stratospheric water vapor measurements during CHEOPS-3, Geophys. Res. Lett., 18(4), 771-774, 1991.

Ovarlez, J. and Ovarlez, H.: Stratospheric water vapor content evolution during EASOE, Geophys. Res. Lett., 21(13), 1235-1238, 1994.

Pan, L., Solomon, S., Randel, W., Lamarque, J. F., Hess, P., Gille, J., Chiou, E. W., and McCormick, M. P.: Hemispheric asymmetries and seasonal variations of the lowermost stratospheric water 
vapour and ozone derived from SAGE II data, J. Geophys. Res., 102(D23), 28 177-28 184, 1997.

Peters, D. and Waugh, D. W.: Influence of barotropic shear on the poleward advection of upper-tropospheric air, J. Atmos. Sci., 53, 3031-3013, 1996.

Pfister, L., Selkirk, H. B., Jensen, E. J., Podolske, J., Sachse, G., Avery, M., Schoeberl, M. R., Mahoney, M. J., and Richard, E.: Processes controlling water vapor in the winter Arctic tropopause region, J. Geophys. Res., 108(D5), 8314, doi:10.1029/2001JD001067, 2003.

Poulida, O., Dickerson, R. P., and Heymsfield, A.: Stratospheretroposphere exchange in a midlatitude mesoscale convective complex 1 observations, J. Geophys. Res., 101, 6823-6836, 1996.

Randel, W. J., Wu, F., Gettelman, A., Russell III, J. M., Zawodny, J. M., and Oltmans, J.: Seasonal variation of water vapor in the lower stratosphere in Halogen Occultation Experiment data, J. Geophys. Res., 106(D13), 14313-14326, 2001.

Randel, W. J., Wu, F., Oltmans, S. J., Rosenlof, K., and Nedoluha, G.: Interannual changes of stratospheric water vapor and correlations with tropical tropopause temperatures, J. Atmos. Sci., 61, 2133-2148, 2004.

Ray, E. A., Moore, F. L., Elkins, J. W., Dutton, G. S., Fahey, D. W., Vömel, H., Oltmans, S. J., Rosenlof, K. H.: Transport into the northern hemisphere lowermost stratosphere revealed by in situ tracer measurements, J. Geophys. Res., 104, 26 565-26 580, 1999.

Shapiro, M. A.: Turbulent mixing within tropopause folds as a mechanism for the exchange of chemical constituents between the stratosphere and the troposphere, J. Atmos. Sci., 37, 9941004, 1980

Scheeren H. A., Fischer, H., Lelieveld, J., Hoor, P., Rudolph, J., Arnold, F., Bregman, B., Bruehl, C., Engel, A., van der Veen, C., and Brunner, D.: Reactive organic species in the northern extratropical lowermost stratosphere: Seasonal variability and implications for OH, J. Geophys. Res., 108(D24), 4805, doi:10.1029/2003JD003650, 2003.

Schiller, C., Afchine, A., Eicke, N., Feigl, C., Fischer, H., Giez, A., Konopka, P., Schlager, H., Tuitjer, F., Wienhold, F. G., and Zöger, M.: Ice particle formation and sedimentation in the tropopause region: A case study based on in situ measurements of total water during POLSTAR 1997, Geophys. Res. Lett., 26(14), 22192222, 1999.

Siegmund, P. C., van Velthoven, P. F. J., and Kerder, H.: Crosstropopause transport in the extratropical northern winter hemisphere, diagnosed from high resolution ECMWF data, Quart. J. Roy. Meteorol. Soc., 122, 1921-1941, 1996.
Sigmond, M., Meloen, J., and Siegmund, P. C.: Stratospheretroposphere exchange in an extratropical cyclone, calculated with a Lagrangian method, Ann. Geophys., 18, 573-582, 2000, http://www.ann-geophys.net/18/573/2000/.

Simmons, A. J., Untch, A., Jakob, C., Kallberg, P., and Unden, P.: Stratospheric water vapour and tropical tropopause temperatures in ECMWF analyses and multi-year simulations, Quart. J. Roy. Meteorol Soc., 125, 353-386, 1999.

Sprenger, M. and Wernli H.: A northern hemispheric climatology of cross-tropopause exchange for the ERA15 time period (1979-1993), J. Geophys. Res., 108(D12), 8521, doi:10.1029/2002JD002636, 2003.

Traub, M. and Lelieveld, J.: Cross-tropopause transport over the eastern Mediterranean, J. Geophys. Res., 108(D23), 4712, doi:10.1029/2003JD003754, 2003.

Vaughan, G. and Timmis, C.: Transport of near-tropopause air into the lower midlatitude stratosphere, Quart. J. Roy. Meteorol. Soc., 124, 1559-1578, 1998.

Vömel, H., Rummukainen, M., Kivi, R., Karhu, J., Turunen, T., Kyrö, E., Rosen, J., Kjome, N., and Oltmans, S.: Dehydration and sedimentation of ice particles in the Arctic stratospheric vortex, Geophys. Res. Lett., 24, 795-798, 1997.

Vömel, H., Yushkov, V., Khaykin, S., Korshunov, L., Kyrö, E., and Kivi, R.: Intercomparisons of stratospheric water vapor sensors: FLASH-B and NOAA/CMDL frost point hygrometer, J. Atmos. Oceanic Technol., in press, 2007.

Wei, M.-Y.: A new formulation of the exchange of mass and trace constituents between the stratosphere and the troposphere, J. Atmos. Sci., 44, 3079-3086, 1987.

Wernli, H. and Bourqui, M.: A Lagrangian "1-year climatology" of (deep) cross-tropopause exchange in the extratropical Northern Hemisphere, J. Geophys. Res., 107(D2), 4021, doi:10.1029/2001JD000812, 2002.

Wirth, V. and Egger, J.: Diagnosing extratropical synoptic-scale stratosphere-troposphere exchange: A case study, Quart. J. Roy. Meteorol. Soc., 125, 635-655, 1999.

Yushkov, V., Astakhov, V., and Merkulov, S.: Optical balloon hygrometer for upper-troposphere and stratosphere water vapor measurements, Optical Remote Sensing of the Atmosphere and Clouds, edited by: Wang, J., Wu, B., Ogawa, T., and Guans, Z.H., Proc. SPIE, vol. 3501, pp. 439-445, 1998.

Yushkov, V., Merkulov, S., Astakhov, V., Pommereau, J. P., and Garnier, A.: A Lyman alpha hygrometer for long duration IR Montgolfier during the THESEO Lagrangian Experiment, Proc. 5th European Ozone Workshop, EC Air Pollution Report 73, available through request to general@ozone-sec.ch.cam.ac.uk, 400-403, 2000. 